\title{
DOCUMENTING LIVING MONUMENTS IN INDONESIA: METHODOLOGY FOR SUSTAINABLE UTILITY
}

\author{
Febriyanti S. $^{\mathrm{a}, *}$, Nadia Purwestri ${ }^{\mathrm{a}}$ \\ ${ }^{a}$ Documentation Center for Architecture Indonesia (Pusat Dokumentasi Arsitektur Indonesia), \\ Jl. Ridwan II no.21 Patal Senayan, Jakarta 12210, Indonesia - \\ pda@pda-id.org / www.pda-id.org
}

KEY WORDS: Documentation, Cultural Heritage, Indonesia, Digital Drawing, Conservation, Living Monument

\begin{abstract}
:
The systematic documentation of cultural heritage in Indonesia has been developed after the establishment of Bataviaasch Genootschap van Kunsten en Wetenschappen (1778) and De Oudheidkundige Dienst (1913) by the Netherlands Indies government. After Indonesian independent, the tasks of cultural heritage documentation take over by The Ministry of Culture (now become The Ministry of Education of Culture) with focus on the ancient and classical heritage, so called dead monument. The needed of comprehensive documentation data regarding cultural heritage become significant issues since the government and private sector pay attention to the preservation of heritage building in the urban site, so called living monument. The archives of original drawing plan many times do not fit with the existing condition, while the conservation plan demands a document such as built drawing plan to work on. The technology, methodology and system to provide such comprehensive document of heritage building and site become important, to produce good conservation plan and heritage building regular maintenance. It means the products will have a sustainable and various utility values.
\end{abstract}

Since 1994, Documentation Centre for Architecture - Indonesia (PDA), has established to meet the needs of a comprehensive data of heritage building (living monuments), to utilized as basic document for conservation planning. Not only provide document of the digital drawing such site plan, plan, elevation, section and details of architecture elements, but also document of historic research, material analysis and completed with diagnosis and mapping of building damages. This manuscript is about PDA field experience, working in this subject issue

\section{INTRODUCTION}

\subsection{The Background}

The registration and documentation on cultural heritages were basically started from the data base that has made by government of Dutch Indies ever since. After the Indonesian Independence in 1945, the main institution that taking care of the cultural heritage was The Directorate of Archaeological Office, under the Ministry of Education and Culture. Since the background of most employees in the directorate were educated as archaeologist and anthropologist, the subjects that become the main focus were the ancient heritage as megaliths, relics of the prehistoric, temples, and structure from the classical period. Those objects mostly located in hinterland and suburb area, as they function as place for shrines or worships that never been inhabited. The ancient cities such Sriwijaya Kingdom in South Sumatera and Majapahit Kingdom in East Java that also become subjects to cover, could be only traced the ruins because it has abandoned and uninhabited since seven centuries ago. The preservation effort for those objects mentioned above has done since the Dutch Indies period and being continued by Indonesia government up to now. It becomes major attention since years.

The heritage cities in Indonesia that still being inhabited and thrive become major cities were mostly formed by the arriving of Islam in Indonesia around $12^{\text {th }}-16^{\text {th }}$ centuries. Many historic building from this Islamic period - such the keraton (the Javanese word for palace), and mosques - were still can be found relatively intact and being occupied by the communities ever since this period until today. Cirebon, Banten, Surakarta, Demak and Yogyakarta are some of the cities that still kept the trace of Islam architectural heritage relatively intact.

Another fact was the ground plan of many Indonesian towns and cities, especially in Java, was originally laid down during the colonial era in $17^{\text {th }}-19^{\text {th }}$ centuries (Gill, 1998). These cities later on developed and become large cities such Jakarta, Semarang and Surabaya, located in north coast of Java. Until the early independence of 50s, there were quite numbers of heritage architectures still exist, occupied and re-use for new function. Not to disregard the vernacular architecture in heritage kampongs or villages that also still occupied as living monument but because most of the historic buildings from Islam, Chinese and Dutch legacy situated in the city center, are still occupied as a living monument, have endangered and threatened by the demolitions and destruction of city developments, the increase of sea level that cause flood, material deterioration, being abandoned and lack of good infrastructure maintenance. This happened because of most of Indonesian cities do not have comprehensive city master plan,

\footnotetext{
* Corresponding author. This is useful to know for communication with the appropriate person in cases with more than one author.
} 
good governance, lack of attention by the municipality and no rigid regulations to manage the heritage cities and buildings.

\subsection{The Law and Regulations}

In 1931 the Dutch Indies government has issued The Monument Ordonantie no.19 as national law to protect the historic buildings. After independence the Indonesian government under the Ministry of Education and Culture has issued the Law no.5 year 1992 regarding The Objects of Cultural Heritage. Later on, the law has upgraded, revised, and replaced by the Law no.11 year 2011 become the Law of Cultural Heritage. This law is not only covering the objects but also the sites, natures, tangible and intangible heritages. However those laws above act as a general umbrella and up to now there are no government regulations sign by the president or minister that act as a technical and detail instruction that could be clearly applied.

\subsection{The Increase of Awareness}

Beginning from the 1970s and 1980s, the awareness to preserve the heritage buildings as living monuments has been raised. In the 70s, Ali Sadikin as the Jakarta Governor at that time has done the first significant and massive preservation and revitalization project in Kota. It's a heritage district in North Jakarta as a $17^{\text {th }}$ century Dutch settlement with numbers of heritage buildings from $17^{\text {th }}$ to early $20^{\text {th }}$ century periods and various styles. By his great visions, Ali Sadikin preserved some significant heritage buildings and re-use as museums (Jakarta Historical Museum, Puppet Museum and Ceramic and Art Museum). This massive project has not only supported by the Jakarta's municipality, and foreign experts, but also involves the Tarumanagara University from the architecture department to make documentation regarding the Kota area. The awareness of preservation has intervened the field of architecture since then. This project becomes the embryo of preservation education in Tarumanagara University majoring architecture. Later on the interest to develop this program become important issues and has been increase in other universities in Indonesia. In the 1980s many preservation movements by communities have established. But the preservation and heritage organizations increase in significant numbers in the 90s and it become more rigid and solid by the establishment of Indonesia Heritage Trust act as umbrella for those heritage organizations. These organizations and universities later on become partners for government institutions and municipality in doing documentation and research regarding heritage building.

However, up to now there is no technical standard regulation regarding on how to do the building documentation. Each government institutions, universities and organizations are using their own form that suit with their needs. Informally it's been actively since 1994; Documentation Centre for Architecture was legally established in 2002 to fill the needs of comprehensive heritage building documentation. It's not only for the database and research purposes but also for the need of preservation and development of heritage building in the future. The documentation products intend to have sustainable values.

\section{LIVING MONUMENTS IN INDONESIA}

The living monuments in Indonesia can be summarized from a course of Indonesian Architecture which represents every period in the Indonesian history, different forms and technique that reflects the cultural diversity in each region. The contribution of the diverse tradition also has an important role in characterized the Indonesian architecture. This following general chronology of Indonesian Architecture tried to describe all the influences that contribute to the formation of Indonesian architecture.

\subsection{Vernacular Architecture}

The vernacular architecture of Indonesia is part of an ancient building tradition in Southeast Asia as well as shared Austronesian ancestry. This vernacular Indonesian Architecture means the traditional Indonesian house in all its variant of many regional forms. Despite of the variety of forms and techniques which represent the cultural diversity in the whole archipelago, it can be abstracted in a number of common themes and principles. Those are: Timber Structure, Elevated Roof, Stone Foundation, Dominant Roof, Adaptation to Climate and Contour and The Ritually Ordered Space (Widodo, 2004). The roof shapes of vernacular architecture, later on were being adopted in design by several Dutch architects whom work in Indonesia early $20^{\text {th }}$ century.

\subsection{Classical Heritage of Indonesia}

Classical architectural heritage in Indonesia was influenced by the Hinduism and Buddhism culture. Candi-a tower like structure made of stone or bricks-is the main form of the building from this period. In this period, the architecture Indonesia encounters a new principle-ordering principles that organize the spatial hierarchy, axis and orientation. Although most of the heritage buildings in this period were not inhabited as the living monuments (mostly function as a worship temples), it has an important role in the Indonesian architecture. Later on, the principles and ornaments of these Candi (temples) influenced the design of some Dutch architects whom work in Indonesia early $20^{\text {th }}$ century.

\subsection{Islamic Tradition}

The spread of Islam through the archipelago from the $12^{\text {th }}$ century influenced the Indonesian Architecture and introduce a new building types-Mosques, tombs and Keraton (palaces). With the advent of Islam, Indonesian Architecture has new principle - the new direction (direction of Qiblat)—which guided to built a Mosque. The emergence of tomb architecture, distinctive palaces and the development of coastal cities are the most significant from this period. Islam entered Indonesia through the adaptation and re-interpretation of the local culture that has been there before. Reinvented and reinterpreted of the existing architecture to suit with the Muslim requirements had occurred.

\subsection{Chinese Tradition}

The contact between Chinese and Indonesian was started from $5^{\text {th }}$ century. These Chinese people brought their traditional architecture and spread it through the archipelago. Traditional Chinese living monuments in Indonesia consist of; Chinese residences, shop houses and temples. Those buildings have the characteristic of the curved roof, row houses and the dominant red color in temple.

\subsection{European Tradition}

The arrival of the Europeans to Indonesia in the $16^{\text {th }}$ century to found the spice-a lucrative trading commodity at that time- 
also brought an influence in terms of culture and architecture. Spanish, Portuguese, Dutch and the British introduce a new building type: forts. The fort is not only serving as a military purpose but also as a trading post, gradually it grows into a complete small town within the wall. Subsequently fort became the embryo of a larger city. In this period the archipelago also became acquainted with Christianity and Catholicism. Church began to be built. The earlier Dutch building in Indonesia was a faithful copy from Europe. The types are from massive grand single buildings such town hall, courts, warehouses, up to row houses and villas. More than a century later; the Dutch architecture began to adapt the local climate and architecture. The Indies style houses arise. It is a synthesis of European NeoClassic with the indigenous architecture. When many Dutch architects arrived in Indonesia in the early of $20^{\text {th }}$ century, they found the dominance of Neo-Classical architecture derived from earlier century. These architects then tried to define the Indonesian architecture. Some architects such as Henri Maclaine Pont and Herman Th, Karsten tried to extract the local ideas and then realized through the use of modern Western construction techniques. While another group of architects such as C.P. Wolff Schoemaker and A.F. Aalbers tried to bring the latest ideas from the West to Indonesia and quoting the local elements. These architects design various buildings such trade offices, bank, train stations, schools, markets and houses, etc.

\subsection{Early Independence}

Indonesian architecture in the early years of independence was still influenced by the Dutch Modernist, this is due to the fact that many Indonesian architects studying in the Netherlands of working for the Dutch architecture offices before the World War II. They replaced the Dutch architects who returned to their country following the enforcement of the nationalization program by the Indonesian government. This nationalization program resulted historical continuity between modern architecture and traditional Indonesian architecture Dutch East Indies ceased. Modernism at this time occurs in several contexts: newly independent Indonesia and the Cold War were going on. Modernism in Indonesia when it is associated with nation building projects and the imagining of Indonesia will be progressive from Soekarno-the first President of Indonesia. Many monumental buildings have built such stadium, offices, mosques, etc.

\section{METHODOLOGY OF DOCUMENTING LIVING} MONUMENTS

Documentation Centre for Architecture has develop the documentation methodology based on field experience that combine with the standard format that has been use by several international institutions such Historic American Buildings Survey (HABS) and Historic American Engineering Record (HAER) under The National Park Service in United State of America, Rijksdienst Cultureel Erfgoed in Netherlands and ICOMOS.

\subsection{The challenges to documenting the living monuments}

The challenges to documenting the living monuments in Indonesia are:

\subsubsection{Technical issues}

1. As living monument, most of the buildings are still occupied

2. The location are in the high density area in city centre
3. Many cases, as built drawing and the historic archives of the heritage building do not provide or sometimes not easily access by public.

4. The documentation of heritage buildings that have done previously were mostly only cover from the archaeological and basic architectural point of views, and lack of historic buildings structure and construction point of views. It means lack of collaboration between multidisciplines.

\subsubsection{Non Technical issues}

1. There are no formal detail regulations and technical guidelines regarding documentation have been issued by Indonesian government or institutions before.

2. If there any technical guidelines mostly are kept by government institutions and not disseminated to public.

\subsection{Inventory of Heritage Buildings}

The first step to document the living monuments is to do the inventory of heritage buildings. This step is intended to set up a database of heritage buildings in a city or district or a country. PDA starts the inventory of heritage building in Jakarta since 1999. The inventory form was referring to ICOMOS. The most important part of the inventory is to formulate the inventory form based on the needed information and the complexity of the heritage building. The inventory form will guided the surveyor to collect data in the field survey, as well as to guide the researcher during their research. The inventory form is also the beginning of database. During the process of the project inventory and identification of Forts in Indonesia, in order to compose a good and usable inventory form, PDA should made adjustments and revisions of the form in several times. This guideline has been tried, tested and revised during the process of the inventory and identification of Forts project, to prove that it was easy applied by the local partner surveyor who did the field survey and at a time it could applicable for further purposes.

\subsection{Comprehensive Heritage Buildings Documentation}

Respond to some challenges and issues that mentioned in subchapter 3.1., PDA tries to formulate the methodology of comprehensive heritage buildings documentation.

\subsubsection{Documentation}

\subsubsection{Building Identification}

The preliminary step before documenting the heritage building is to identify:

The existing plan. The surveyor should re-draw by made sketch of existing plan (if the current technical drawing do not provide). Each room will be specified named by code numbers. For example: I.1, I.2, etc. II.1, II.2, etc. I for first floor, II for second floor, etc. This system has used to avoid the confusion of existing room name and can inform the location precisely. It also to anticipate confuse by any changes of the room name in its future use. This first data later on will use as key plan for the next step.

The building elements. Each heritage buildings have specific elements regarding its style and period. The knowledge of architecture history is important. Each element will be identified in code number, alphabetical orders, and its location. For example: arch (a1, a2.), base (b1, b2), column (c1, c.2), door (d1, d2), etc. The numbers specify its type, form, style, materials, colors and its location. For example: 
Column 1 (c1): Doric type, bricks construction, plastered and painted white.

Photo Documentation. The existing photo documentation will cover the building exterior (4 sides), interior (each rooms), building elements, ornaments, mechanical electrical and plumbing systems including site drainage.

Product. Schematic Drawing Plan (un-scaled), Schematic Key Plan of Building Elements (un-scaled), Table of building elements lists (with photo of the element, explanation of form, style, materials, colors, location and its code number).

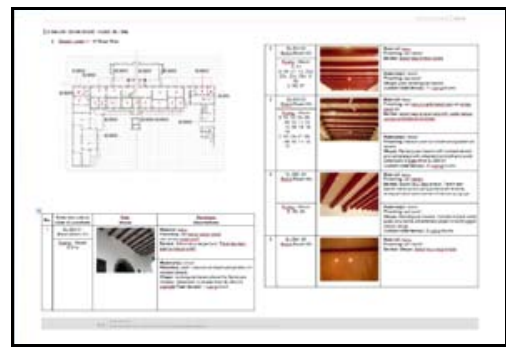

Figure 1. Sample of Identification document. It shows key plan and list of building elements.

\subsubsection{Re-Measure}

Schematic Drawing for Re-Measurement Reference. The result of the A.1.a., will use as re-measure reference. The schematic drawing plan will be completed with notations to inform which part of the building should be measured. The schematic drawing also provide for section, elevation and building elements.

The principal. The re-measure refer and fit with the existing condition. The measurement only done for object that could be seen (many cases that the objects covered by furniture, because the building is still occupied).

Tracing the ornaments. The ornaments patterns are tracing on the transparent plastic sheets and it will be re-traced on the tracing paper, and it will be scanned, transform to digital data. The equipments. The equipments that use for measure will depend and adjusted on the building condition that still occupied. Mostly measurement tapes and Leica Disto (Laser Distance Measurer) are used. For building elevation, floor elevation, building height, and sites are measured by theodolite and GPS. These equipments are quite fit with the condition of heritage building that mostly located in the high density area. In the building that located in the open space the utilization of Leica 3D Laser Scanner is enabled. But the rental price for this equipment is quite expensive in Indonesia. The Product. Schematic Drawing Plan, Section and Elevation (un-scaled), with notation; Schematic Drawing of building elements (elevation, section), with notations; Digital data of ornaments tracing.

\subsubsection{Re-Drawing}

Re-drawing. The objectives are to provide a comprehensive as built drawing based on the existing condition that can be used by architects for make the building conservation plan.

Verification. The re-drawing process is done in the field, in the same time with the measurement process, so the result will directly could be verify and validate.

Technical Drawing Format.

Architecture Drawing: Plans, Sections, Elevations, Roof Plan, Ceiling Plan, Floor Plan, Key Plan of building elements in digital (AutoCAD) presented in scale 1:500 (large building), 1:100 (medium-small building) and completed with bar scale, axis and grid system. This system will be use to specify the location (of elements) precisely.

Element Drawing: Arch, Base, Columns, etc It scale 1:50 or 1:20, depend on its size.

Product. Technical Drawing Document in A1 or A3 paper size.

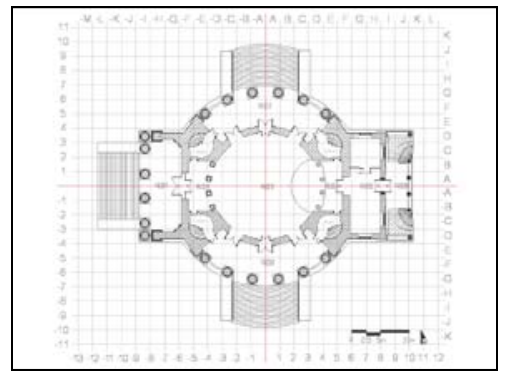

Figure 3. Sample of technical drawing plan, with grid and axis system.

\subsubsection{Research}

Research on history and architecture of the living monuments has been carried out with the aim to collect as much as possible the information of the building to support the planning for the conservation of the building. In many cases the information from this research can be used for other publication; commercial book etc.

\subsubsection{History}

To do the historic research, PDA refer to HABS/HAER standard and guidelines for historic documentation.

- Standard I. Historical Documentation Follows a Research Design that Responds to Needs Identified in the Planning Process

- Standard II. Historical Documentation Employs an Appropriate Methodology to Obtain the Information Required by The Research Design

- Standard III. The Results of Historical Documentation Are Assessed Against the Research Design and Integrated into the Planning Process. (HABS/HAER 1994)

The main resources of the information are The National Archive and the National Library of Indonesia. The archives of the owner or user of the monuments and source persons give also many important information for the historic research. Since the Indonesian shared its cultural heritage with the Dutch, the Dutch institutions and libraries are becoming important sources.

The assistance of an expert on history, guided the PDA's researchers during the process of the research project, particularly to analyze the information and write the report. PDA's researchers did research on the historical information on the heritage building as; the ownership, former function as well as the changing of the building function; date of construction; the architects; the builders; and the original drawings and photos of the building. The historian and the research coordinator will write a historical context narrative. Context means how the property fits into the history and social structure of a given period of time and geographic location. (OAHP, 2007). Historical research report will provides important information concerning to the living monuments. It can be used by the conservation architects, historians, and other profession as well as the student

\subsubsection{Architecture}


Architectural research has been done parallel to the historic research. The important step in this research is observation in the monuments itself. It covers the condition of the building, the elements and ornaments, the material and also the alteration and addition of the building. PDA's research coordinator will write a general architectural narrative which consists of the architectural character, architectural style, description of the exterior and interior and description of the site. The purpose of the written architectural information is to supplement the information provided by measured drawings and photographs, so the descriptions need not be exacting in detail if graphics are available. The descriptions should be clear and concise and touch on all significant features of the building. (HABS/HAER, 1994)

\subsubsection{Foundation Excavation}

In some projects this work is needed to get data and information about the foundation structure system, construction, condition and materials. The excavation should be done and conducted by archaeologist team in term to protect any significant artifacts founded during the process. The structure engineer will accompanied during the process to analyze the structure and construction system and its condition. During this process some materials also take to be examined. The product will be Report of Foundation excavation and Technical drawing of building foundation.

\subsubsection{Building Material}

Laboratory Process. The samples of materials are taken to be analyzed its composition, quality, classifications and strength. In Indonesia, our institution has cooperation with Balai Konservasi Borobudur (Conservation Research of Borobudur) in Yogyakarta. The institution has archaeological and material experts, support with comprehensive laboratory equipment.

Objects to observe. It covers materials of plasters, mortars, bricks, woods (wood frame, beams, roof truss, etc).

Product. Report of material compositions, completed with drawings, tables, etc.

\subsubsection{Construction and Structure}

Object to observe: building construction system, condition, and strength. It also covers the soil condition.

Scope of works. Loading test (for beam and floor), wall structure strength test, and soil test.

Product. Report of structure research completed with drawings, tables, etc.

\subsubsection{Mechanical, Electrical, Plumbing Installation (Building Utility)}

Object to observe: Existing condition of ME system (lighting, electrical, air condition), Plumbing system (gutter, site drainage, hydrology system) etc.

The principle. Mapping all the system and equipment that could be seen by eyes. Metal detector could be use for support the information that still hides behind walls or other material. Product. Report of ME and Plumbing system, completed with key plan drawing.

\subsubsection{Technical Inspection, Diagnosis and Analysis of} Building Condition and Damages

All the documentation data that has been gathered and compiled will be diagnosed, analyzed.

1. Architecture
- Covering building alteration, addition and changes (since built up to current condition).

- The methodology by compare the original drawing (base on archives research) with the technical drawing (current condition), and analysis of building material and construction.

2. Elements and Material

- Covering elements and material damage, degradation, the causes and effects, structural and non structural.

- The damages of each element will be determined in lists and code number based on types, material, and location. The key plan and tables will present all the information.

- All key plan drawings will be completed with bar scale, axis and grid system. This system will be use to specify the location (of elements damage and location).

3. Structure and Construction

Valuation of the structure and construction existing condition has objectives to provide data building structure reliability.

4. Mechanical, Electrical, and Plumbing System Valuation of the system provides data of its reliability.

5. The reliability valuation on structure, construction, mechanical, electrical, etc, should be compare with the building standard regulation (Law of Building no.28 issued in 2008 by Ministry of Public Works).

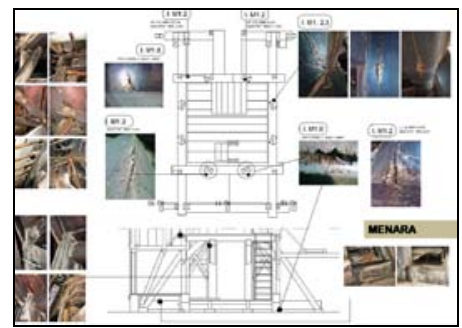

Figure 5. Drawing sample of elements and structural diagnosis and analysis, PDA project for Jakarta Historic Museum.

\subsection{Sustainable Values}

\subsubsection{Inventory of Heritage Building}

The database which built and established after the inventory project serves information on living monuments in Indonesia to the public. PDA established an online database of Forts in Indonesia since 2010, after the completion of the inventory and identification of forts project. This online database can be observed in www.bentengindonesia.org. It had been used by the student, researcher, government, historians and other profession who interested to know about forts in Indonesia. The database also has an important role in the decision to nominate several forts building to be listed as a national heritage. Before the database of forts in Indonesia established there were only 28 forts had been listed as a National Heritages (1999-2007). After the database was established the number of forts that became a National Heritage was increased to 49 forts (2007-2010). The inventory form PDA's made, also influence and has been used by several inventory of heritage building project throughout Indonesia. Recently, this inventory form was used for an inventory project in 10 heritage cities in Indonesia that stipulated by The Ministry of Public Works in collaboration with The Indonesian Heritage Trust. 


\subsubsection{Documentation of Heritage Building}

The whole documentation information that have described above will be useful for make the building conservation planning.

1. Technical Drawing

This information will be directly use by architects and engineer to make any conservation and repair plan.

2. Architecture

This information will be used as reference during the planning for restoration process. It can help to decide and arrange the restoration method and technique. It will be used to restore the building in its original state.

3. Technical Inspection, diagnosis-analysis, inventory of building damages

- This information will be used to make plans of building and structural repair that have specified in details on each elements, material, type and locations.

- The grid system that has mentioned above - with size as per module - will be easily used by building estimator to determine the volume of conservation work that further can produce the budget plan and time schedule for conservation works.

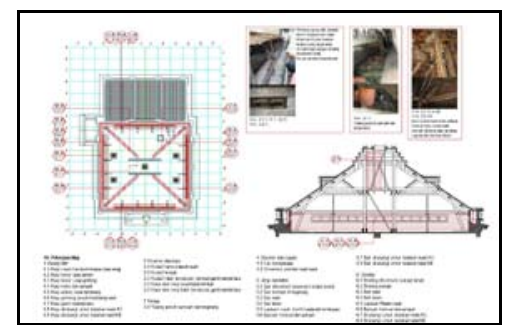

Figure 6. Sample of conservation planning, based on documentation of damage inventory and mapping. PDA project for Bank Indonesia ex De Javasche Bank in Solo, 2009.

This documentation methodology and products have proven could respond to the needs of comprehensive documentation for preservation and conservation project, easy understandable by high rank experts, professionals, contractors up to the low rank craftsman who works in the project.

\section{CONCLUSIONS}

The whole documents that produce since the first step up to the planning process can be utilized for monitoring tools during the construction process to guarantee the quality of conservation product. The construction process of heritage building conservation should be documented and recorded on each step. The documentation product will be use for building maintenance in the future. The documentation of living monuments actually was an endless process and a sustainable product.

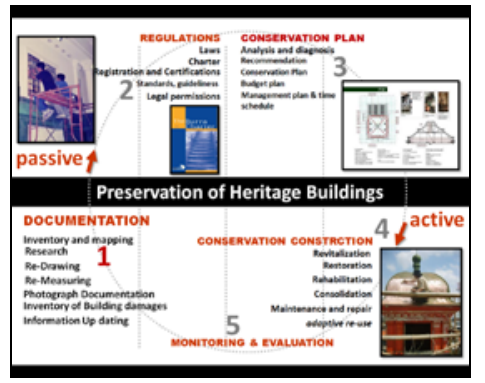

Figure 5. An endless process of documentation for each step of heritage building preservation shows its sustainability.

\section{REFERENCES}

References from Books:

Gill, Ronald, 1998. Town Formation in $19^{\text {th }}$ - Century Java. In: Indonesian Heritage - Architecture, Archipelago Press, Singapore, pp. 106-107

Pusat Dokumentasi Arsitektur, 2011. Pengantar panduan konservasi bangunan bersejarah masa kolonial. Pusat Dokumentasi Arsitektur, Jakarta.

Tjahjono, Gunawan and John Miksic, 1998. The Genesis of an urban Tradition. In: Indonesian Heritage : Architecture, Archipelago Press, Singapore, pp.84-85.

\section{References from Other Literature:}

Widodo, Johannes, 2004. Modernitas Arsitektur Indonesia, paper on mAAN workshop on Inventory of Asian Modern Heritage, Universitas Bung Hatta, Padang, 7 Juli 2004.

\section{References from websites:}

National Park Service, Heritage Documentation Programs, Standard and Guidelines, United State of America http://www.nps.gov/history/hdp/standards/standards.htm

Colorado Office of Archaeology and Historic Preservation / Colorado Historical Society (OAHP/CHS). 2007. Historic Resource Documentation, Standards For Level I, II, and III Documentation. OAHP Publication \#1595, http://www.historycolorado.org/sites/default/files/files/OAHP/cr forms_edumat/pdfs/1595_2007.pdf

Rijksdienst Cultureel Erfgoed, Monumentenregister http://monumentenregister.cultureelerfgoed.nl/php/main.php

ICOMOS, Documentation Centre, http://www.icomos.org/en/about-the-centre

Balai Konservasi Borobudur, http://www.konservasiborobudur.org/

\section{Law and Regulations:}

Historic American Buildings Survey/Historic American Engineering Record, 1994. HABS/HAER guidelines : recording structures and sites with HABS measured drawings. U.S. Dept. of the Interior, National Park Service, Cultural Resources, Historic American Buildings Survey/Historic American Engineering Record, Washington.

Rijksdienst voor de Monumentenzorg, 1987. Inventarisatie jongere bouwkunst en stedebouw (1850-1940) : handleiding. Rijksdienst voor de Monumentenzorg, 's-Gravenhage.

\section{AKNOWLEDGEMENTS}

Febriyanti S. and Nadia Purwestri

Upon graduated as an architect in 1994, both has been active in inventory, documentation and research of heritage building and district, architecture exhibition, conservation of living monuments and publication. Both are of the co-founders of PDA, currently serves as Executive Directors of PDA (www.pda-id.org). 